\title{
Methanol oxidation behaviors of PtRu nanoparticles deposited onto binary carbon supports for direct methanol fuel cells
}

\author{
Soo-Jin Park ${ }^{1,2, »}$, Jeong-Min Park ${ }^{1,2}$, and Seul-Yi Lee ${ }^{1,2}$ \\ ${ }^{1}$ Korea CCS R\&D Center, Korea Institute of Energy Research, Daejeon 305-343, Korea \\ ${ }^{2}$ Department of Chemistry, Inha University, Incheon 402-751, Korea
}

\section{Article Info}

Received 15 December 2012

Accepted 26 January 2013

*Corresponding Author

E-mail: sjpark@inha.ac.kr

Tel: $+82-32-860-8438$

\section{Open Access}

DOI: http://dx.doi.org/

10.5714/CL.2013.14.2.121

This is an Open Access article distributed under the terms of the Creative Commons Attribution Non-Commercial License (http://creativecommons.org/licenses/ by-nc/3.0/) which permits unrestricted non-commercial use, distribution, and reproduction in any medium, provided the original work is properly cited.

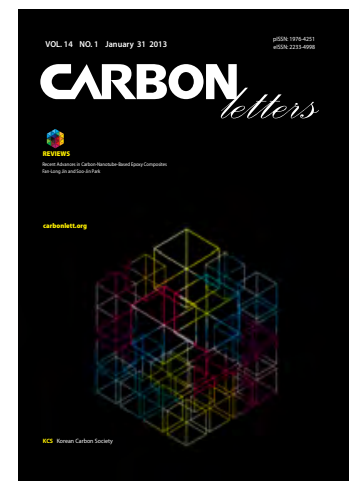

http://carbonlett.org

pISSN: $1976-4251$

elSSN: 2233-4998

Copyright $\odot$ Korean Carbon Society

\begin{abstract}
In this study, PtRu nanoparticles deposited on binary carbon supports were developed for use in direct methanol fuel cells using carbon blacks (CBs) and multi-walled carbon nanotubes (MWCNTs). The particle sizes and morphological structures of the catalysts were analyzed using X-ray diffraction and transmission electron microscopy, and the PtRu loading content was determined using an inductively coupled plasma-mass spectrometer. The electrocatalytic characteristics for methanol oxidation were evaluated by means of cyclic voltammetry with $1 \mathrm{M} \mathrm{CH}_{3} \mathrm{OH}$ in a $0.5 \mathrm{M} \mathrm{H}_{2} \mathrm{SO}_{4}$ solution as the electrolyte. The PtRu particle sizes and the loading level were found to be dependent on the mixing ratio of the two carbon materials. The electroactivity of the catalysts increased with an increasing MWCNT content, reaching a maximum at 30\% MWCNTs, and subsequently decreased. This was attributed to the introduction of MWCNTs as a secondary support, which provided a highly accessible surface area and caused morphological changes in the carbon supports. Consequently, the PtRu nanoparticles deposited on the binary support exhibited better performance than those deposited on the single support, and the best performance was obtained when the mass ratio of CBs to MWCNTs was 70:30.
\end{abstract}

Key words: PtRu nanoparticles, binary carbon supports, direct methanol fuel cells, methanol oxidation

\section{Introduction}

In recent years, direct methanol fuel cells (DMFCs) have gained a reputation as one of the most attractive power sources for terrestrial electrical vehicles owing to their high power density achievable at low temperatures. Their performance is nevertheless limited because of the slow kinetics of methanol electro-oxidation at the anode, catalyst poisoning, and the methanol crossover phenomenon. The poisoning of the anode catalysts by carbon monoxide, an intermediate of the anodic methanol oxidation, is one of the causes of the slow kinetics of the anode reaction, which is a major challenge that needs to be overcome to increase the catalyst efficiency and power density $[1,2]$.

Among the precious metals, $\mathrm{Pt}$ is most commonly used as a catalyst because Pt shows the highest activity for electro-oxidation of methanol. However, the performance of a pure $\mathrm{Pt}$ catalyst is not satisfactory owing to the formation of strongly adsorbed intermediates. Poisoning of the Pt surface by $\mathrm{CO}$ during methanol electro-oxidation is the major reason for the slow kinetics. CO can strongly adsorb onto the surface of the pure Pt catalyst and form a Pt$\mathrm{CO}$ species, which blocks the catalytic active sites. To solve this problem, advanced anode catalyst designs that are based on a bi-functional mechanism, have been suggested; in these designs, cocatalysts are used and $\mathrm{Ru}$ is added to the Pt catalysts. The best results have been reported for binary PtRu catalysts, because Ru easily removes $\mathrm{CO}$ from Pt. Therefore, binary PtRu catalysts are regarded as appropriate materials for anode catalysts of DMFCs $[3,4]$. 
Many researchers have attempted to improve the activity of the PtRu catalyst by various approaches. The electrocatalytic activity is strongly dependent on particle size, dispersibility, support materials, and surface conditions [5]. In addition, it is necessary to decrease the amount of precious metal used and the loading level on the support materials. Therefore, the support materials have been identified as an important parameter because they contribute to the overall catalyst characteristics. $\mathrm{PtRu}$ supported on carbon has gained considerable attention as an important catalyst for DMFC electrodes [6,7]. Carbon-based materials are widely used as support materials because of their textural, electronic, adsorption, and molecular sieving properties. Carbon blacks (CBs) have been widely used as electrocatalyst supports because of their high electric conductivity and surface area and their low cost $[8,9]$. Recently, a graphitic nanostructured carbon material, multi-walled nanotubes (MWCNTs), has been the object of focus as a catalyst support for DMFCs owing to its high strength, low density, and high electrical and thermal conductivity $[10,11]$.

A single carbon support, however, may not easily facilitate control of an electrode structure to achieve high conductivity and porosity and good morphology. Sakaguchi et al. [12] and Wang et al. [13] proposed the concept of adopting binary carbon supports for use in liquid electrolyte fuel cells and demonstrated an improved utilization of Pt catalysts. It has also been reported that the use of binary carbon supported catalysts has increased.

In this study, we prepared PtRu nanoparticles deposited on binary carbon supports (CBs and MWCNTs) as a catalyst for DMFCs. To optimize electrocatalytic activity, the CB/MWCNT supports were impregnated with PtRu nanoparticles with good dispersibility. The electrochemical characteristics of the $\mathrm{PtRu} / \mathrm{CB} / \mathrm{MWCNT}$ catalysts were examined for methanol oxidation in the DMFCs.

\section{Materials and Methods}

\subsection{Materials and sample preparation}

Binary carbon supports were prepared by mixing CBs (Hi Black 420B, Korea Carbon Corporation) and MWCNTs (Nano Solution Company) with different mixing ratios. The samples were designated as MWCNT 0, MWCNT 10, MWCNT 30, MWCNT 50, and MWCNT 100 according to the MWCNT weight content of $0,10,30,50$, and $100 \%$, respectively. Prior to the preparation of the PtRu catalysts, the residual chemicals in the carbon materials were removed using nitric acid for $3 \mathrm{~h}$. Both CBs and MWCNTs were washed several times with distilled water and dried in a vacuum oven at $110^{\circ} \mathrm{C}$. The $\mathrm{CB} / \mathrm{MWCNT}$ supports were suspended in distilled water and ultrasonically stirred for $30 \mathrm{~min}$. Then, the metal precursors, $\mathrm{H}_{2} \mathrm{PtCl}_{6}$ and $\mathrm{RuCl}_{3}$ (Aldrich Co.), were dissolved in distilled water and added dropwise to the $\mathrm{CB} / \mathrm{MWCNT}$ slurry. The metal precursors were prepared to contain 1:1 ratios, and the total loading of metal precursors in $\mathrm{CB}$ / MWCNT supports was $20 \mathrm{wt} \%$. Next, a $5 \mathrm{M} \mathrm{NaOH}$ solution was added to adjust the $\mathrm{pH}$ of the solution. Then, $\mathrm{HCHO}$, a reducing agent, was added to the solution and stirred at $85^{\circ} \mathrm{C}$ for $5 \mathrm{~h}$ to reduce the $\mathrm{Pt}$ and $\mathrm{Ru}$ metals. The experiment was conducted under a stream of argon gas to remove organic by-products. The catalysts were then dried in a vacuum oven at $70^{\circ} \mathrm{C}$ for $12 \mathrm{~h}$

\subsection{Characterization}

$\mathrm{PtRu}$ loading levels of the catalyst were calculated using an ELAN 6100 inductively coupled plasma-mass spectrometer (ICP-MS). Structural properties of the catalyst were investigated using X-ray diffraction (XRD) performed using a Rigaku D/MAX 2200V/PC X-ray diffractometer with $\mathrm{Cu} \mathrm{K}_{\alpha}$ radiation. The $2 \theta$ angular regions between $20^{\circ}$ and $85^{\circ}$ were investigated at a scan rate of $5 \% \mathrm{~min}$. A transmission electron microscope (TEM, A JEM 2100F) was used to observe the surface properties of the catalyst. Before obtaining electron micrographs, the catalyst samples were ultrasonically dispersed in ethyl alcohol, and a drop of the resultant dispersion was deposited and dried on a Lacey carbon film suspended on a copper grid. The $\mathrm{N}_{2}$ adsorption isotherms were measured at $77 \mathrm{~K}$ using a Micromeritics TriStar 3000. Prior to nitrogen adsorption, the samples were treated in vacuum at $573 \mathrm{~K}$ for $6 \mathrm{~h}$. The $\mathrm{N}_{2}$ adsorbed on the $\mathrm{CB} /$ MWCNT support was used to calculate the specific area using the Brunauer- Emmett-Teller (BET) method.

\subsection{Electrochemical properties}

The electrocatalytic behaviors of the catalyst were examined using Autolab with PGSTAT 30 (Eco Chemie, The Netherlands) cyclic voltammetry equipment. The measurements were conducted at $25^{\circ} \mathrm{C}$ in a conventional three-electrode electrochemical cell system consisting of the following electrodes: a Pt wire as a counter electrode, an $\mathrm{Ag} / \mathrm{AgCl}$ reference electrode, and a catalyst sample mixed with carbon paste on a glassy carbon electrode as a working electrode. $1 \mathrm{M} \mathrm{CH}_{3} \mathrm{OH}$ in a $0.5 \mathrm{M} \mathrm{H}_{2} \mathrm{SO}_{4}$ aqueous solution was used as the electrolyte for methanol oxidation measurements, and a $0.5 \mathrm{M} \mathrm{H}_{2} \mathrm{SO}_{4}$ aqueous solution served as the electrolyte for hydrogen oxidation measurements. The potential changed linearly from 300 to $1100 \mathrm{mV} v \mathrm{~s}$. $\mathrm{Ag} / \mathrm{AgCl}$ and was recorded with a scan rate of $20 \mathrm{mV} / \mathrm{s}$. The electrochemical surface area (ECSA) of the catalysts was calculated from the hydrogen desorption region of the voltammogram curves in the $0.5 \mathrm{M} \mathrm{H}_{2} \mathrm{SO}_{4}$ solution.

\section{Results and Discussion}

Fig. 1 shows the XRD patterns of the $\mathrm{PtRu} / \mathrm{CB} / \mathrm{MWCNT}$ catalysts. The first peaks at approximately $26^{\circ}$ are associated with the graphite (002) peak of the CB/MWCNT supports. The intensity of $2 \theta$ at $26^{\circ}$ gradually increased with an increasing MWCNT content, indicating that the addition of MWCNTs had an effect on the crystalline lattice of the carbon supports and that it probably corresponded to structural changes in the CBs/MWCNTs. All of them presented the important characteristic patterns of $\mathrm{Pt}$ face-centered cubic (FCC) crystalline structures at 20, i.e., of $\mathrm{Pt}$ (111) at $40^{\circ}, \mathrm{Pt}(200)$ at $47^{\circ}, \mathrm{Pt}(220)$ at $67^{\circ}$, and $\mathrm{Pt}(311)$ at $80^{\circ}$. The XRD patterns verified that the $\mathrm{CB} / \mathrm{MWCNT}$ support was impregnated with Pt particles. The characteristic peaks of $\mathrm{Ru}$, however, were not clearly seen in the XRD patterns. From the results of the XRD, the Pt particle size ( $L c$, along the $c$ axis) was calculated using the Scherrer equation [10].

$$
L_{c}=\frac{K \lambda}{\beta \cos \theta}
$$




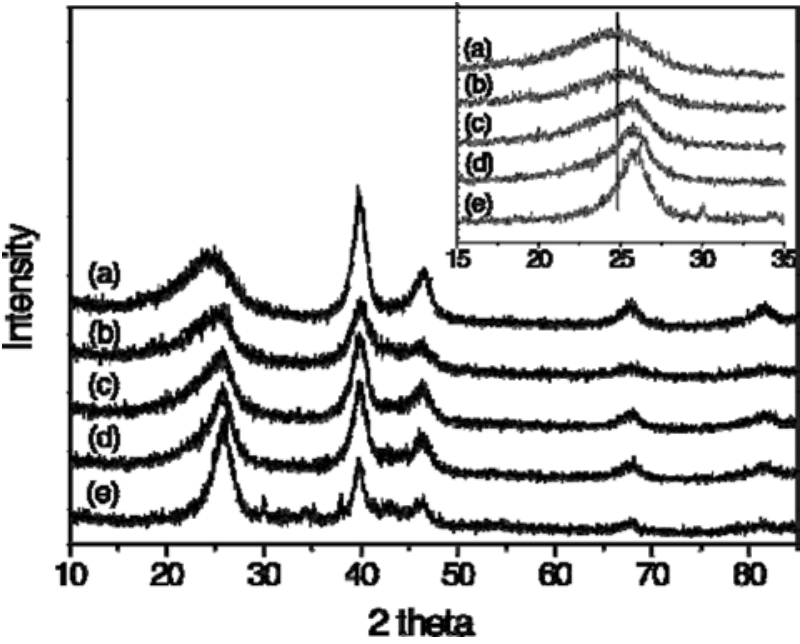

Fig. 1. X-ray diffraction (XRD) patterns of PtRu/CBs/MWCNTs catalysts; (a) MWCNT 0, (b) MWCNT 10, (c) MWCNT 30, (d) MWCNT 50, and (e) MWCNT 100 (inset: XRD patterns of positions of peaks at $26^{\circ}$ ). CBs: carbon blacks, MWCNTs: multi-walled carbon nanotubes.

Table 1. The CSA, ECSA, and Pt utilization of PtRu deposited on CBs/MWCNTs

\begin{tabular}{ccccc} 
Specimens & $\begin{array}{c}\mathrm{Q} \\
(\mathrm{mC})\end{array}$ & $\begin{array}{c}\text { ECSA } \\
\left(\mathrm{m}^{2} / \mathrm{g}\right)\end{array}$ & $\begin{array}{c}\text { CSA } \\
\left(\mathrm{m}^{2} / \mathrm{g}\right)\end{array}$ & $\begin{array}{c}\text { Pt utilization } \\
(\%)\end{array}$ \\
\hline MWCNT0 & 0.13 & 29.59 & 55.12 & 53.53 \\
MWCNT10 & 0.20 & 44.70 & 67.51 & 66.21 \\
MWCNT30 & 0.31 & 55.38 & 71.38 & 77.58 \\
MWCNT50 & 0.26 & 50.81 & 72.14 & 70.43 \\
MWCNT100 & 0.18 & 46.02 & 73.46 & 62.64 \\
\hline
\end{tabular}

CSA: chemical surface area, ECSA: electrochemical surface area, CBs: carbon blacks, MWCNTs: multi-walled carbon nanotubes.

where $\mathrm{K}$ is the Scherrer constant (0.89), $\lambda$ is the wavelength of $\mathrm{X}$ radiation ( 0.154 for $\mathrm{Cu} \mathrm{K \alpha}$ ), $\beta$ is the half-height width of $\mathrm{Pt}(220)$, and $\theta$ is the angle at the peak maximum positioning (unit: radian).

The Pt crystal size obtained from the peak of FCC (220) and the particle sizes determined from TEM results are listed in Table 1. The Pt crystal size decreased gradually from 4.3 to $3.5 \mathrm{~nm}$ with changing MWCNTs ratios. The PtRu particle sizes obtained from TEM images were in agreement with the results calculated from XRD. The decrease in PtRu particle sizes can be related to the increase of specific surface area by increasing the portion of MWCNTs, which have a larger specific surface area than the CBs: The specific surface area, calculated from nitrogen adsorption at $77 \mathrm{~K}$ using the BET method, is $77.1 \mathrm{~m}^{2} / \mathrm{g}$ for CBs and $214.2 \mathrm{~m}^{2} / \mathrm{g}$ for MWCNTs, as shown in Table 1 . Consequently, the specific surface area of the binary carbon supports gradually increased with an increase in MWCNT content. This could lead to the formation of a separate secured area for the deposition of PtRu particles due to the interaction of carbon supports. Therefore, the PtRu particle dispersion improved and the particles became smaller because of the increase in the specific surface area [14].

TEM images show the particle sizes and morphologies of the

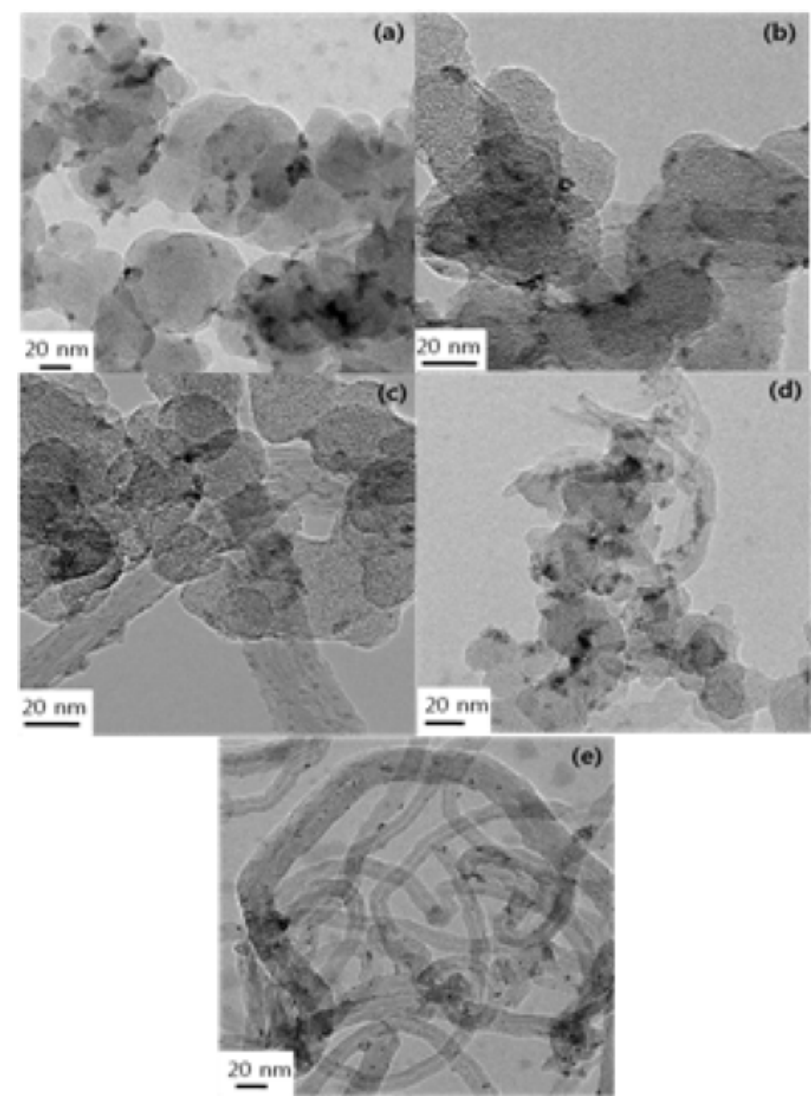

Fig. 2. Transmission electron microscopy images of PtRu/CBs/MWCNTs: (a) MWCNTO, (b) MWCNT 10, (c) MWCNT 30, (d) MWCNT 50, and (e) MWCNT 100. CBs: carbon blacks, MWCNTs: multi-walled carbon nanotubes.

catalysts on the CB/MWCNT support. As seen in Fig. 2, PtRu particles were successfully deposited on the mixed binary carbon supports regardless of mixing ratios of CBs to MWCNTs. $\mathrm{PtRu}$ particle dispersion improved with an increasing MWCNT content, and aggregation was not observed. It can be also seen that the PtRu particles are gradually less evident with an increasing content of MWCNTs. In particular, in MWCNT30, PtRu particles were uniformly deposited on the MWCNT30. The Pt and $\mathrm{Ru}$ content and loading levels of the catalysts were determined from the ICP-MS results (Table 2). The loading level of the catalysts means that the impregnated PtRu weight percent in the carbon materials is $20 \%$, as described in the previous section. The loading level of PtRu deposits may be related to the reaction conditions of PtRu reduction and to the surface characteristics of the carbon supports. In other words, the loading level is probably dependent on the changes in surface conditions related to $P$ t reduction and to changes in the specific surface area owing to variations in the mixing ratios of the two carbon supports.

Fig. 3 shows the cyclic voltammograms (CVs) of the prepared catalysts in a $1 \mathrm{M} \mathrm{H}_{2} \mathrm{SO}_{4}$ solution. In the absence of methanol, typical surface processes for polycrystalline Pt such as hydrogen adsorption/desorption and, to a lesser extent, oxide formation and reduction can be observed in the $\mathrm{CV}$ s recorded on the $\mathrm{Pt} / \mathrm{C}$ composite electrode. The Pt ECSA was calculated from the hydrogen desorption peak areas in the CV curves using the following formula [11]. 
Table 2. Mean size, textural properties and loading contents of the catalysts

\begin{tabular}{|c|c|c|c|c|}
\hline Specimens & Crystalline size $(\mathrm{nm})^{\mathrm{a}}$ & Particle size $(\mathrm{nm})^{\mathrm{b}}$ & Specific surface area $\left(\mathrm{m}^{2} / \mathrm{g}\right)$ & Loading level (mass \%) ${ }^{\mathrm{d}}$ \\
\hline MWCNT0 & $4.3 \pm 0.1$ & $5.0 \pm 0.3$ & 77.1 & 17.7 \\
\hline MWCNT10 & $4.1 \pm 0.2$ & $4.2 \pm 0.1$ & 86.3 & 17.9 \\
\hline MWCNT30 & $3.8 \pm 0.2$ & $3.9 \pm 0.2$ & 119.6 & 18.6 \\
\hline MWCNT50 & $3.7 \pm 0.1$ & $3.6 \pm 0.1$ & 142.7 & 18.2 \\
\hline MWCNT100 & $3.5 \pm 0.1$ & $3.4 \pm 0.1$ & 214.2 & 17.9 \\
\hline
\end{tabular}

MWCNT: multi-walled carbon nanotube.

${ }^{\text {a } M e a s u r e d ~ f r o m ~ X-r a y ~ d i f f r a c t i o n ~ r e s u l t s . ~}$

${ }^{\mathrm{b}}$ Measured from transmission electron microscopy results.

${ }^{c}$ Measured from $\mathrm{N}_{2}$ adsorption isotherms.

${ }^{\mathrm{d}}$ Measured from inductively coupled plasma-mass spectrometer results.

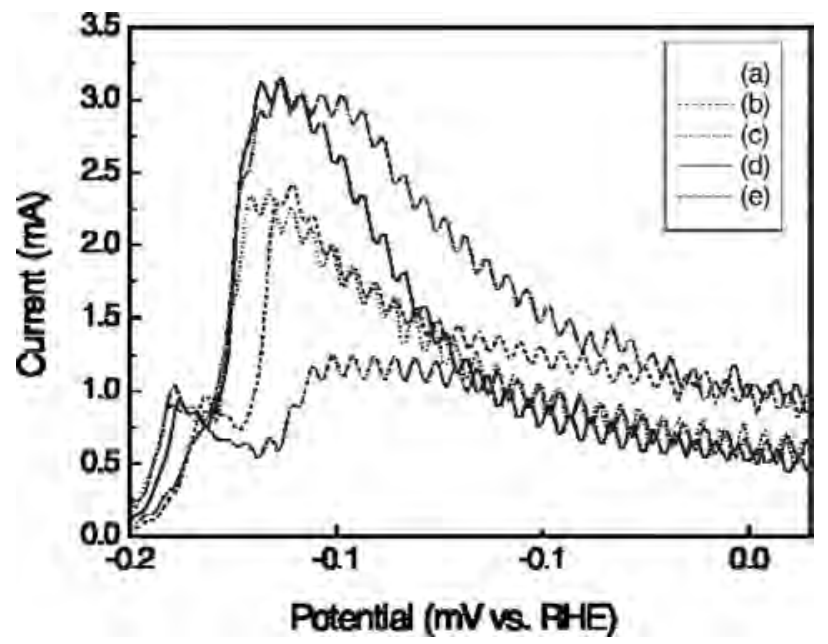

Fig. 3. Hydrogen desorption peaks on cyclic voltammetry of PtRu/ CBS/MWCNTs in $1.0 \mathrm{M} \mathrm{H}_{2} \mathrm{SO}_{4}$ : (a) MWCNTO, (b) MWCNT 10, (c) MWCNT 30 , (d) MWCNT 50, and (e) MWCNT 100. CBs: carbon blacks, MWCNTs: multiwalled carbon nanotubes.

$$
\mathrm{ECSA}=\frac{\mathrm{Q}(\mathrm{mC})}{0.22 \mathrm{mC} / \mathrm{cm}^{2}}
$$

where $\mathrm{Q}$ is the electric charge for hydrogen desorption and the value of the hydrogen adsorption constant for polycrystalline $\mathrm{Pt}$ is $0.22 \mathrm{mC} / \mathrm{cm}^{-2}$.

The calculated ECSA values are shown in Table 1, which also summarizes other catalyst data. The chemical surface area (CSA) of the PtRu catalysts was calculated using the following equation [11]:

$$
\mathrm{CSA}=\frac{6 \times 10^{4}}{\rho \times d}
$$

where $d$ is the mean Pt particle diameter in $\AA$ (from TEM results) and is the density of Pt metal $\left(21.4 \mathrm{~g} / \mathrm{cm}^{2}\right)$. The utilization efficiency can subsequently be calculated using the following formula [11]:

$$
\text { Pt utillization efficiency }=\frac{\text { ECSA }}{C S A}
$$

Generally, catalysts with a smaller particle size had a higher ECSA than those with a larger particle size and distribution.

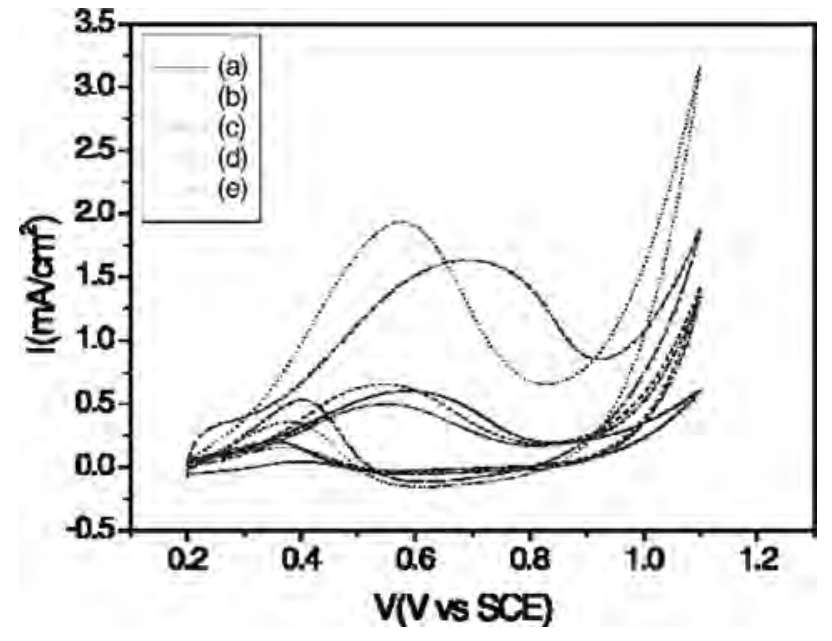

Fig. 4. Cyclic voltammetry of PtRu/CBs/MWCNTs: (a) MWCNTO, (b) MWCNT 10, (c) MWCNT 30, (d) MWCNT 50, and (e) MWCNT 100. CBs: carbon blacks, MWCNTs: multi-walled carbon nanotubes.

Fig. 4 shows the electrocatalytic activity of the catalysts in methanol oxidation. Significant differences in the peak current density and onset potential between the catalysts were observed, thus illustrating the beneficial role of the support materials. A comparison of catalyst CV curves shows that the peak current density of PtRu deposited on binary carbon supports was much higher than that of PtRu deposited on single supports. A definite methanol oxidation peak of the catalyst occurred at $510-690 \mathrm{mV} v s . \mathrm{Ag} / \mathrm{AgCl}$ in a forward scan and an additional anodic peak was seen at 340-420 mV vs. $\mathrm{Ag} / \mathrm{AgCl}$ in a backward scan for each sample. Electrocatalytic activity increased with an increasing MWCNT content, and the highest peak current density was obtained at MWCNT 30 . However, a further increase in MWCNT content to above $30 \%$ decreased the current density, resulting in a loss in electroactivity. This decrease may be related to the large particle size and the decrease in the effective surface area of the catalyst.

\section{Summary}

In this study, binary carbon-supported PtRu catalysts were prepared using two carbon supports, i.e., CBs and MWCNTs, 
in different mixing ratios. PtRu catalysts show that $\mathrm{CBs} / \mathrm{MW}$ CNTs were homogeneously impregnated with PtRu. The PtRu nanoparticle size was found to decrease from $5.0 \mathrm{~nm}$ to $3.3 \mathrm{~nm}$ with an increasing MWCNT content from $0 \%$ to $100 \%$. This decrease may be attributed to the increase in the specific surface area with the increasing MWCNT content. The CVs for methanol oxidation showed that the methanol oxidation peak varied depending on the surface properties and morphology of the carbon supports. It was thus found that the binary carbon supports could significantly affect the methanol oxidation activity of anode electrocatalysts in DMFCs. Moreover, morphological control of the binary carbon supports may be an effective means of increasing the Pt utilization of Pt-based catalysts.

\section{Acknowledgements}

We acknowledge the financial support by grants from Korea CCS R\&D Center, funded by the Ministry of Education, Science and Technology of Korean government.

\section{References}

[1] Gerteisen D. Transient and steady-state analysis of catalyst poisoning and mixed potential formation in direct methanol fuel cells. J Power Sources, 195, 6719 (2010). http://dx.doi.org/10.1016/j. jpowsour.2010.04.004

[2] Jung N, Cho YH, Ahn M, Lim JW, Kang YS, Chung DY, Kim J, Cho YH, Sung YE. Methanol-tolerant cathode electrode structure composed of heterogeneous composites to overcome methanol crossover effects for direct methanol fuel cell. Int $\mathrm{J}$ Hydrogen Energy, 36, 15731 (2011). http://dx.doi.org/10.1016/j. ijhydene.2011.09.054.

[3] Harish S, Baranton S, Coutanceau C, Joseph J. Microwave assisted polyol method for the preparation of $\mathrm{Pt} / \mathrm{C}, \mathrm{Ru} / \mathrm{C}$ and $\mathrm{PtRu} / \mathrm{C}$ nanoparticles and its application in electrooxidation of methanol. J Power Sources, 214, 33 (2012). http://dx.doi.org/10.1016/j.jpowsour.2012.04.045.

[4] Park SJ, Park JM. Preparation and characteristic of platinum catalyst deposited on boron-doped carbon nanotubes. Curr Appl Phys, 12, 1248 (2012). http://dx.doi.org/10.1016/j.cap.2012.02.057.
[5] Burstein GT, Barnett CJ, Kucernak AR, Williams KR. Aspects of the anodic oxidation of methanol. Catal Today, 38, 425 (1997). http://dx.doi.org/10.1016/S0920-5861(97)00107-7.

[6] Dinh HN, Ren X, Garzon FH, Piotr Z, Gottesfeld S. Electrocatalysis in direct methanol fuel cells: in-situ probing of PtRu anode catalyst surfaces. J Electroanal Chem, 491, 222 (2000). http://dx.doi. org/10.1016/S0022-0728(00)00271-0.

[7] Kim S, Park SJ. Electroactivity of Pt-Ru/polyaniline composite catalyst-electrodes prepared by electrochemical deposition methods Solid State Ionics, 178, 1915 (2008). http://dx.doi.org/10.1016/j ssi.2007.12.074

[8] Eguiluz KIB, Salazar-Banda GR, Miwa D, Machado SAS, Avaca LA. Effect of the catalyst composition in the Ptx(Ru-Ir)1-x/C system on the electro-oxidation of methanol in acid media. $\mathrm{J}$ Power Sources, 179, 42 (2008). http://dx.doi.org/10.1016/j.jpowsour.2007.12.070.

[9] Bagotzky VS, Vassiliev YB, Khazova OA. Generalized scheme of chemisorption, electrooxidation and electroreduction of simple organic compounds on platinum group metals. J Electroanal Chem, 81, 229 (1977). http://dx.doi.org/10.1016/S0022-0728(77)800193.

[10] Han KI, Lee JS, Park SO, Lee SW, Park YW, Kim H. Studies on the anode catalysts of carbon nanotube for DMFC. Electrochim Acta 50, 791 (2004). http://dx.doi.org/10.1016/j.electacta.2004.01.115.

[11] Knupp SL, Li W, Paschos O, Murray TM, Snyder J, Haldar P. The effect of experimental parameters on the synthesis of carbon nanotube/nanofiber supported platinum by polyol processing techniques. Carbon, 46, 1276 (2008). http://dx.doi.org/10.1016/j.carbon.2008.05.007.

[12] Sakaguchi M, Uematsu K, Sakata A, Sato Y, Sato M. Correlation between wettability of carbon carriers and activity of porous electrodes. Electrochim Acta, 34, 625 (1989). http://dx.doi. org/10.1016/0013-4686(89)85005-4.

[13] Wang X, Hsing IM, Yue PL. Electrochemical characterization of binary carbon supported electrode in polymer electrolyte fuel cells. J Power Sources, 96, 282 (2001). http://dx.doi.org/10.1016/S03787753(00)00625-X

[14] Nam K, Lim S, Kim SK, Peck DH, Jung DH. Mechanical milling of catalyst support for enhancing the performance in fuel cells Powder Technol, 214, 423 (2011). http://dx.doi.org/10.1016/j.powtec.2011.08.041 